\title{
Uzbekistan in the new world order
}

\section{Meryem Kirimli}

To cite this article: Meryem Kirimli (1997) Uzbekistan in the new world order , Central Asian Survey, 16:1, 53-64, DOI: 10.1080/02634939708400969

To link to this article: http://dx.doi.org/10.1080/02634939708400969

$$
\text { 曲 Published online: } 13 \text { Sep } 2007 .
$$

Submit your article to this journal $2 \pi$

$$
\text { Џll Article views: } 142
$$

Q View related articles $\widetilde{ }$

4 Citing articles: 2 View citing articles 둔 
Central Asian Survey (1997), 16(1); 53-64

\title{
Uzbekistan in the new world order*
}

\author{
MERYEM KIRIMLI
}

Since the Uzbek declaration of independence, there exists confusion not only in the outside world, but in the very republic itself about the new place Uzbekistan should take in the changing new world order. Many attempts have been made to answer questions related to foreign policy in the post-independence era as well as the type of political system this new republic will adopt. Questions come to mind such as: Is Uzbekistan part of the Turkic world? Does it also have a share in the Islamic world? Does Uzbekistan have anything to do with the countries of the Middle East? Can Uzbekistan be considered as part of the 'Orient'? Despite its declaration of independence, Uzbekistan still has strong ties to the old centre, Moscow. Is it then appropriate to consider Uzbekistan part of the Western world, if Russia is to be considered as such? The search to solve such puzzles remains undefined in academic circles.

The Uzbek declaration of independence, within the country, and in all the other Central Asian republics, caught many natives by surprise. ${ }^{1}$ There was no structure existent in Uzbekistan ready to tackle the problems of independent statehood. Yesterday's Communist Party nomenklatura suddenly found themselves the representatives of an independent state. As of 1993, some 130 countries in the world recognized Uzbekistan. ${ }^{2}$ It has established diplomatic relations with more than 40 of them ${ }^{3}$ and Uzbek embassies began to be opened in some tens of countries in the 'free world'. Four years after its declaration of independence, Uzbekistan is now a country which has been admitted to many important international organizations, including the United Nations and the OSCE, Organization on Security and Cooperation in Europe.

Consolidation of the new Uzbek state required efforts such as the formation of a new national identity, decolonization, Islamization, Turkification and derussification. All efforts towards handling the aforementioned matters are at the beginning stage. Discussion of such issues was visible in the Uzbek media until the beginning of 1994. However, it soon became difficult for intellectuals and academics in the outside world to monitor or forecast changes in the republic, due to strict control of native export publications by the Uzbek

*This article was prepared within the framework of a NATO institutional fellowship granted to the Department of International Relations, Bilkent University. I avail myself of this opportunity to express my thanks to NATO and to Professor Ali Karaosmanoglu for his support in carrying out this project. My gratitude also goes out to Mr Celil Vefali, an ex-Programme specialist at the RFE/RL Uzbek Service, for enabling me to examine all the archive material of the Uzbek Service at the RFE/RL when it was located in Munich.

Meryem Kirimli is at the Department of International Relations, Bilkent University, Ankara. 


\section{MERYEM KIRIMLI}

administration. Nonetheless, certain signs indicate that the republic is answering some of the vital questions towards defining the future of this newly independent republic.

\section{Problems of Uzbek identity and religion}

Native press articles in Uzbekistan began to draw attention to a need to revitalize the national history. Reinterpretation of so-called 'Uzbek History', the Soviet past, the colonial past, and the emergence of the term 'Uzbek' were all subjects discussed in the media until the end of 1994. Some Uzbek writers also submitted to a belief that 'quarrels about the past are in fact struggles to control the future $\ldots^{4}$ and claimed a need for the appropriate interpretation of Uzbek history and observation of historical events. Such intellectuals believed that it would help to strengthen the destiny of the newly independent republic of Uzbekistan. ${ }^{5}$

Discussions about the specific periods of Uzbek history also began to appear in the Uzbek press. The Timurid period, together with the discussions of the Cedidist ${ }^{6}$ legacy were the two events that left a strong mark on the historical consciousness of the Uzbek people. ${ }^{7}$ Attempts have also been made to discuss the origin of the Uzbek people, dating as far back as the 16th century. Uzbek writers Ahmadali Asqarov and Boribay Ahmedov claim that the history of the Uzbeks started at least as early as the 10th century. The same writers also suggest that 'Uzbeks are not Turks but rather a Turkic group, the language of Uzbeks is Turkic but there is a great difference between the Turkish and the Uzbek languages'. 8

Attempts to discuss certain periods in Central Asian history result in an Uzbek effort to find or define the "Golden Age'9 of the Uzbek people. It seems difficult to assign the Timurid period as the golden age to only the Uzbeks, based merely on the fact that the tomb of Timur and many monumental buildings of the Timurid dynasty are within the borders of today's Uzbekistan. On the other hand, the Timurid legacy is unique not only to present day Uzbeks; all Central Asian peoples and their ancestors have a share in it. The idea of claiming the Timurid period as an era unique and common to the whole of Central Asian people will undermine the present-day identities of all the individual republics in Central Asia. Despite this fact, Uzbekistan has declared the current year as the 'Year of Timur'. It has also been forecast that in the case of regional unity in Central Asia, whether it be built upon Islamic or pan-Turkic roots, Uzbekistan is likely to display the tendency of attempting to play the regional hegemon or the dominating nation. ${ }^{10}$ However, it remains to be seen whether Uzbeks will attempt to dominate the region by claiming themselves as the inheritors of the Timurid legacy.

Discussion of the Cedidist legacy also brings confusion to the maintenance of Uzbek identity. Uzbek academicians like Begali Kasimov complained that efforts in Uzbekistan are not sufficient to study and republish the Cedidist material in the country. He points to the similarity of events in the first and last decades of the contemporary age. ${ }^{11}$ Two months after this interview, Prof. Begali 
Kasimov was appointed chairman of a new department at Tashkent State University. It was reported that this new department will focus on studying the Cedidist period in Uzbek literature. ${ }^{12}$

At the beginning of this century, the original Cedidist movement started in Central Asia with the strong influence of the Crimean Tatar intellectual and publisher Ismail Bey Gaspirali, who, with his Tercuman/Perevodchik, was widely read among the intellectuals of Turko-Muslims in Central Asia, the Caucasus, the Volga-Ural region, Ottoman Turkey and as far away as Eastern Turkestan and India. ${ }^{13}$ In 1914, for instance, Jadid schools in the Samarqand oblast' were using books published in Kazan, Bakhchisarai, Tehran, and Bombay. ${ }^{14}$ One Uzbek scholar, Abdujabbar A. Abduvakhitov, depicts the Cedids as follows:

During the first decade of Soviet rule nearly all Jadid movement activists were executed, including Munawwar-Qari, Abdulla Qadiriy, Chulpon, Abdur Rauf Fitrat, Usmon Nosir, Tawallo, and many others. Their deaths do not mean that the movement was defeated. In my opinion, Jadidism succeeded for the following reasons: The movement gave birth to the awakening of national self-determination of Central Asian people, gave them modern education, and brought positive changes in their political thinking. It was due to the Jadids' efforts that there was a cultural renaissance in Central Asia. They wrote outstanding novels, poems, and dramas, which are now famous not only in Central Asia but also in many other countries. Jadidism was a real step forward to the national liberation of the Central Asian people. Even in the field of religion there were many positive achievements, including modernization of attitudes, renovation of past practices, and adaptation of Islam to modern conditions. Jadidism made Islam a vital force ... Seventy years of Soviet repression were not able to stop the influence of Jadidism ... Rather Jadidism and revivalism are two stages of one process of gaining real independence and establishing of a sovereign state. ${ }^{15}$

The Crimean Tatar, Volga-Ural, Turkestani and Azerbaijani Cedidists were not only in close contact with each other, but were also aware of the ideas of the parallel-minded Turkish/Ottoman intellectuals. ${ }^{16}$ Publications, after independence of the republic, began gradually to mention the Cedidist leaders such as Mahmudxoja Behbudi (1875-1918), Abdullo Avlaniy (1878-1934), Abdurrauf Fitrat (1886-1938), Cholpan (Abdulhamit Suleyman) (1897-1938). ${ }^{17}$ Except Mahmudxoja Behbudi, all of these and many other Uzbek intellectuals became the victims of the Stalinist Great Terror against the native intelligentsia in Central Asia. Particularly, Mahmudxoja Behbudi, Abdullo Avlaniy, and Abdurrauf Fitrat followed the ideas of the Crimean Tatar Cedidist leader Ismail Bey Gaspirali. It should also be noted that this fact was admitted in the postindependent Uzbek publications. ${ }^{18}$ In the post-independence literature, a leading Cedidist, Abdurrauf Fitrat, was depicted as one of the outstanding poets, writers and dramatists, teachers and publicists who studied in the madrasas of Bukhara and Istanbul. In 1909, he was admitted to the Dar'ulfunun (University) of Istanbul and studied there until 1913. He wrote an article entitled 'Yasasin Turkluk, Yasasin Islam'. (Long live Turkness, Long live Islam), in the pages of Ulug Turkistan (Great Turkistan) dated 1917. ${ }^{19}$ The title of the article clearly indicates the tendencies of the Cedidists in the area. 
In present-day Uzbekistan, there seems to be another fear of undermining 'Uzbekness' should there be too much emphasis placed upon the nature of 'Turkic' or 'Turkish' character. Nasimcan Rahmanov stated the following, '... The understanding of "Turkness" is finding such a place in our vocabulary that the concept of "Uzbek" is becoming increasingly meaningless and soulless' ${ }^{20}$ It seems that the strong regionalism or tribalism of the writer caused him anxiety over losing Uzbek identity as a result of acquiring a more general Turkic identity. The statement also indicates that at least a certain group of intellectuals are worried about losing the loyalty of the Uzbek people to their newly formed republic, and seem to view such behaviour as a threat to the Uzbek fatherland. This is also clear evidence of confusion and departure by some Uzbek intellectuals from the views of the Cedidists. Furthermore, it also demonstrates the success of the Bolshevik 'divide and rule' policy for 70 years.

The Bolshevik administration divided Central Asia into different groups in order to divide determinedly the area ethnically. It was an artificial and absurd practice, alien to the characteristics of the region. However, during the 70-year long Soviet rule, each of the Central Asian republics, though unnaturally, have developed different identities. This phenomenon has complicated the crises of identity, particularly in Uzbekistan and generally in the entirety of Central Asia. Thus, it seems natural for the people of Central Asia to pay specific attention to the search for their cultural and religious roots. This trend seems to be particularly strong in Uzbekistan, compared to neighbouring republics. The dominant position of the Uzbek population in the republic also gave impetus to the activities in promoting Islam and Islamic studies, albeit unofficially.

In Uzbekistan today, rediscovery of the Cedidist legacy of the late 19th and the early 20 th century, among a group of intellectuals is a sign that the Uzbek tendency is to depart from religious fundamentalism, and to contribute to a secular and modern trend. Cedidist ideas of pre-revolutionary Turkestan aimed to unite both the Turkic and the Islamic past of the society, while also acknowledging the conditions of the modern age. The outstanding Cedidist poet, Abdulhamid Suleyman (Cholpan) wrote in his famous poem Qozgalis (Revolt) that the aim of the Cedidists was to get rid of the oppression of the traditional leadership. ${ }^{21}$ In particular, the Young Bukharans during the pre-revolutionary era struggled against traditionalist-conservatives in the Emirate. Those Young Bukharans were the intelligentsia who wanted to establish close ties with Istanbul, with special regard to matters of education. Some of the leading members of this group visited or lived in Turkey after the 1908 Revolution, including Abdurrauf Fitrat, Muhammedsharif Sufizade and Mahmudxoja Behbudi. 22

In Uzbekistan, there is a very close relationship between the ideas of Cedidists and the interpretation of Islamic traditions and principles. Unofficial religious study groups in Fergana, Namangan and Andijan, have reportedly studied pre-revolutionary Cedidist books. ${ }^{23}$ It is true that in Uzbekistan, religious tendencies are deep-rooted and far stronger than in any other Central Asian Turkic republic. It is the Fergana Valley which is the centre of informal religious 
activities. It has been reported that it is the old Cedidist ideas that these activities draw their inspiration from. ${ }^{24}$ History also indicates that if the control is left to the people, there will definitely be more inclination towards Islamic and Turkic traditional tendencies. In such cases, of course, the authority of the current leadership in Uzbekistan will be challenged with a new generation of leaders with different assessments and values. President Karimov seemed well aware of this fact when he banned the opposition parties of Birlik and Erk from political activity in the country and exiled the leaders of the two parties. At the same time, Karimov also aimed to secure his rear when he acted decidedly against the Islamic democratic opposition in neighbouring Tajikistan.

National identity and religion are the two pillars of Central Asian leaders, and they are exercising them to consolidate their new states. Thus, Islam Karimov of Uzbekistan began to cite in his speeches the Cedidist leaders whose names were forbidden during Soviet rule. Although the names of Abdulla Qadiri, Abdulhamid Suleyman (Cholpan), Abdurrauf Fitrat, and Osman Nasir were rehabilitated in the mid-1950s, not much actual writing has been done about them. According to the Uzbek president, the fairest judgement about those who were 'martyred for the freedom of our people and the land' arrived with the attainment of Uzbek independence. ${ }^{25}$ The religious heritage of Central Asian Muslims has also found support in the republican leadership. In the words of Professor Kemal Karpat, '... today Islam in Central Asia is a source of national culture and an avenue for political leaders to court popular support and identify themselves with the masses. ${ }^{26}$ Islam Karimov describes two holy days of Islam, the Ramadan Xayt (Eid-Bayram) and Qurban Xayt as the two important milestones of the spiritual and religious heritage of the Uzbek people. Karimov also stated that, observance of 'such events will help to awaken the respect and belief of the people in their leaders and to the administration'. ${ }^{27}$

Furthermore, President Karimov rejects the assessment that the observance of religious holy days is a tribute to Islamicist groups. He argues that the official observance of the two holy days should be seen as the awakening of traditional values among the people, and particularly towards respect for their forebears. ${ }^{28}$

Uzbek President Islam Karimov reported early in 1992 that when he visited Mecca, he thanked God for the delivery of freedom and independence to the Uzbek people. He wrote the following: 'When we were allowed to enter Kaaba, I prayed to God for my people. I believed that I did not go there for an empty purpose. We have received so much respect and not with an empty purpose, it is due to the good grace of God. ${ }^{29}$ This behaviour, however, is not unique to Karimov. It seems to be the current attitude among the majority of leaders in Central Asia. Kazakh President Nursultan Nazarbayev also publicized his visit to Ravza-i Mutahhara in Madina, where he prayed before the tomb of the Prophet Mohammed, 'thanking God for the delivery of freedom to the Kazakh people', while in tears. ${ }^{30}$ 


\section{Is Karimov an 'Oriental despot'?}

It seems that those who engage in deciphering the path taken by newly independent Uzbekistan must necessarily ask themselves the above-stated question. Is the president of Uzbekistan an 'Oriental despot'? This question is the natural conclusion of those who engage in the pre-revolutionary history of the area. It is almost impossible not to draw parallels with autocratic leaders of the pre-revolutionary Turkestan Khanates of Bukhara and Khiva, with that of the current Uzbek leader after examining the violations of human rights and abuses visited upon the Uzbek opposition party leaders. Jeri Laber, an executive director of the International Human Rights Watch/Helsinki Organization, said that 'Uzbekistan remains one of the last bastions of Communist-type dictatorship on the territory of the former Soviet Union'. ${ }^{31}$ Members of opposition parties have been beaten by the police in the streets or arrested on false charges in Uzbekistan. Karimov has banned all opposition parties, maintains tight media censorship and oversees a strict supervision of government personnel. He has rebuffed Western criticism of human rights abuses by citing a need for strong executive powers to guard against danger from conflicts in neighbouring Afghanistan and Tajikistan. Uzbek human rights activists are even barred from attending conferences and meetings abroad. Uzbek secret police have several times attempted to abduct opposition figures in attendance at such conferences, and such members of the opposition are currently either in jail or in exile hiding from the Uzbek secret police. During one such conference organized in Turkey, the Uzbek Embassy withdrew from the conference due to an invitation to one of the exiled Uzbek opposition leaders to the same conference in 1994.

The exiled leader of the Uzbek opposition party Erk, Muhammed Salih, made a speech in Borne in the Netherlands on 10 June 1995, and the following is an excerpt of that speech in which he has reported the current political, economic conditions and criticized the current Uzbek leadership: ${ }^{32}$

The most frequent slogan by Uzbek parliamentarians is, 'Long Live the "Silence"!' and 'Long live our smartest president'. In the Uzbek constitution, there is a space for a democratic president, however in practice it does not exist. Instead there is an autocrat. There is no single branch of the government that exists without the control of the centre. Even agreements between trading firms are considered legal only after obtaining presidential approval. All of the foreign firms in Uzbekistan are subject to presidential permission. The basis of our free market economy is the black market. Bribery and corruption are the foundations of our economy. An official who does not receive and give bribes, or those who do not engage in corruption immediately finds himself out of a job. $95 \%$ of all the population in Uzbekistan is poverty-stricken. The rich are the ones who comprise the other $5 \%$ who belong to the nomenklatura. That is to say, the deputies, judges and police officers. There is no middle class in the country. On the one hand, there is a small group of bribed rich and on the other, there is a magnificent army of the poor ... In our constitution, there are articles related to the multi-party system. There are four parties (in Uzbekistan) whose activities are officially permitted. All of these (parties) consist of old communists, which equate to 'pocket parties'. That is to say, they are in the pocket of the 'monarch'. The real 
opposition parties, the ones which do not fit into 'his' (the monarch, i.e. the president) pocket have for years been persecuted and terrorized.

What is the primary objection of the opposition to the Karimov regime? During the pre-Independence years, in 1988 and 1989, we asked the administration to launch reform programmes in politics and the economy. Those were the reforms which would have made us step forward towards a process of gradual democratization. We have supported stability in the country. It was impossible to achieve reform without stability. Unfortunately, the administration misused our position. They used it instead to strengthen their control, and as a result, Uzbekistan was made a police-state. Today in Uzbekistan, there is no freedom but there is stability. However, this stability looks more like the stability of a graveyard (or the silence of a graveyard). The (word) stability is a wonderful card in the hands of our dictators. Western leaders who are the fans of human rights and democracy, cannot oppose our dictators in the face of this card (stability).

(Some sentences omitted.)

Uzbekistan is the cradle of Turkish civilization. There are currently 23 million people living in Uzbekistan. It would be wrong to assume that these people are hungry only for bread. Our people are in need of freedom together with bread. I would like to have my voice reach my brothers in Turkey. Turkey should help Uzbekistan in its democratization process. We do not need Turkish investment and credits that will help the current regime in Uzbekistan to become even stronger!

Of course Turkey is right in considering Uzbekistan as brother, and so its president Karimov. However, people who are suffering under the oppression of 'brother Karimov' are also your brothers. I wish Turkish government would pay more attention to the suffering of these masses.

\section{Uzbek economy}

Economic development is believed to be the key to maintaining social and political stability in Uzbekistan. Irrigation policies and efforts to increase cotton production in Uzbekistan are one of the reasons that have led to present economic conditions in this newly independent republic. It has also led to the desiccation of the Aral Sea and is threatening the very survival of the Karakalpak people in the area. During the Soviet period, industrial investment in the area has been neglected at the expense of short-term agricultural goals. However, seven decades of Soviet economic, military, and political policy has made the area dependent upon the old centre of Moscow despite the four years that have elapsed since independence. One dimension of the so-called 'cotton affair' is related to Uzbek corruption practices during the Sharaf Rashidov years. Rashidov was accused of manipulating cotton production figures during the Gorbachev administration, which consequently launched a crackdown in Uzbekistan. Among the Uzbek people, this 'cotton affair' assumed symbolic importance beyond the surface claims of corruption. For many Uzbek nationals, the 'cotton affair' also became a pretext for Moscow's persecution along ethnic grounds of local Uzbek officialdom. ${ }^{33}$ Adil Yaqubov, an Uzbek writer reportedly exposed the 'cotton monoculture', at the USSR Congress of the People's Deputies, as an event 'that put the Uzbek people into a worse condition than the AfricanAmericans of nineteenth-century America'. ${ }^{34}$ The Uzbek President Islam 


\section{MERYEM KIRIMLI}

Karimov was also claimed to support this cause, and made a speech commemorating the 75th birthday of Sharaf Rashidov in 1992. The following is an excerpt of that speech which was published later. ${ }^{35}$

This should not be forgotten that this unique personality (Rashidov) was on the one hand trying to protect the national interests, on the other hand, he was trying to put into practice orders, coming from the centre, which were in contrast with the fundamental interests (of the Uzbek people) ... Even during the worst times, Sharaf Rashidov fulfilled the obligations of a true son to his nation. He tried to soften orders coming from the centre and (he was trying) to find money to support the development of our nation. The political conditions of those days were such that, we were obliged to beg for goods we needed from the centre. It was given from the wealth taken from us-from the territory of our Uzbekistan.

The Uzbek president elaborated further in one of his speeches in April 1993, during a meeting with a group of Uzbek intellectuals about the Uzbek cotton and gold which was required to be sent to Moscow. According to the calculations of the president, during the preceding 15 years the centre obtained from Uzbekistan at least 35 billion dollars worth of gold and cotton. ${ }^{36}$

With its population of some 22 million, Uzbekistan is one of the leading countries in the region with considerable potential both in human resources, but also as a source of economic and social conflict. According to Bahadur Ashanov, Head of the External Economic Relations Committee for Forecasting and Statistics in the Cabinet of Ministers of Uzbekistan: ${ }^{37}$

Uzbekistan imports $80 \%$ of the wheat, all the tea and sugar, $40 \%$ of the meat and meat products, and $35 \%$ of the milk and milk products its residents use. We export more than $70 \%$ of our cotton, more than $50 \%$ of our fruit. Since Uzbekistan imports $80 \%$ of its needs ... we understand that cotton is the only real opportunity for us to earn hard currency.

Cotton monoculture is the only agricultural commodity that Uzbeks can use to obtain foreign currency. Nevertheless, cotton monoculture also has forced the country to concentrate on grain production to feed its growing and young population. More than 60 per cent of the population are children and teenagers younger than 25 years of age. ${ }^{38}$ It has also been suggested that this youth factor will act to meet the demands of other Muslim countries in labour shortages as relations and diplomatic contacts improve in the future.

As for the transition to the free market economy, Uzbek leadership is taking the slow path. In this vein, Uzbek President Islam Karimov stated the following: 'I am absolutely sure of the need of transforming the economy (to the free market economy) only it must be step by step. ${ }^{39}$

\section{Uzbekistan and her neighbours}

As do all the other Central Asian republics, Uzbekistan still has close economic and military relations with the old centre, Moscow, and the new Russia. Relations with Russia have always, for all the republics in the area, occupied the number one position in the agenda of newly independent CAS (Central Asian 
States) governments. The old big brother and the attendant ethnic Russians in each republic were always taken care of for the sake of not hurting relations with Moscow. Special privileges were extended to the Slavic population. However, the Uzbek president recently stated that Uzbekistan 'is against dual citizenship' of the Slavic population residing in the republic. ${ }^{40}$ Furthermore, Uzbek President Islam Karimov said that Uzbekistan needs, 'a democratic Russia which accepts us in an equal and an all-round way, which welcomes our successes and is ready to hold out its hand and help us, thus finding support, strength, help and advantage for itself. This is the kind of Russia we consider close to us. ${ }^{, 4}$

It is also interesting to study the aims and future plans of the current Uzbek leadership towards another neighbouring country, Afghanistan, in which a considerable number of 'Turkestanis' live. Still another question arises in determining the existence of a fear by Uzbek officials from the potential fundamentalists in Tajikistan. ${ }^{42}$ It has been reported that one in every four persons in Tajikistan is an Uzbek. ${ }^{43}$ Could this be the source of fear in the Karimov government? It would be interesting to know whether Karimov has a real fear of fundamentalism or whether he only fears losing his position in Uzbekistan. It was on this point that Karimov complained about the current Tajik leadership during a news conference organized after Russian premier Viktor Chernomyrdin visited Uzbekistan, in July 1995. Karimov stated the following: 'I would like to add that the shortsighted leaders of Tajikistan, and above all those who are currently in power, are acting very shortsightedly in hoping that someone else's border guards and troops will defend them while they sit it out in Dushanbe. ${ }^{44}$ Policies of the Uzbek leadership towards Tajikistan seem far more complicated and calculating than the above statements indicate because, as one analyst reported, 'The Uzbek intervention in Tajikistan could lead to the identification of the Karimov government with Moscow imperialism despite the fact that it is Moscow which is being manipulated by Tashkent on the political situation in Tajikistan., 45

As for China, since its independence Uzbekistan is seeking to establish close economic ties. Trade between China and Central Asian countries, including Uzbekistan, has boomed since the collapse of the Soviet Union in 1991. As of the last quarter of 1994, China and Uzbekistan have signed 15 agreements on technical, trade and economic deals. Trade between the two countries reportedly has risen to 80 million dollars for the first seven months of 1994 against 98 million dollars for all of $1993 .^{46}$ Although Uzbekistan does not share a border with China, there are some 20,000 Uzbeks living in the Chinese province of Xinjiang. At the same time, a small number of Uighurs also live in Uzbek territory. Xinjiang region is home not only to Uzbeks but to Kazakhs, Kyrgyz, Uighurs and other Muslim minorities who share a common heritage with all the Turko-Muslims of Central Asian republics. Chinese authorities seem especially cautious about the tensions in the Xinjiang area especially after the independence of the Central Asian republics. Besides, a group of Uighurs living in Kazakhstan and Kyrgyzstan are a cause of some concern to the Chinese leadership. Chinese authorities are also closely watching the attitudes of Central Asian governments 


\section{MERYEM KIRIMLI}

towards Uighur nationalists in their republic. Any attempt towards encouraging an 'Eastern Turkestani' independence movement will result in spoiling relations with China for the Central Asian countries. It seems that the number one priority of the Chinese side is to prevent any kind of involvement of the newly independent CAS in any activity in the 'Eastern Turkestan' region. Otherwise China seems to be ready to improve economic relations with the region.

\section{Conclusion}

After four years of independence, Uzbekistan is already well on the way to consolidating statehood. All the discussions about past history and prerevolutionary legacy seem an attempt to get rid of the unwanted relics of the colonial past. Seeking the roots of the Uzbeks, and establishing natural cultural, religious, and historical links with the past, are all part of the process of decolonization. A question immediately comes to mind when we speak of decolonization: Are the Central Asian countries currently really independent of the old centre? There are attempts at reinterpreting the past, rewriting the history of their people, reconsidering and rediscovering their cultural and religious roots, and rehabilitating their national and cultural symbols. During the process of decolonization, it is natural not only for Uzbeks but all Turko-Muslim republics and groups of the old Soviet Union to handle the issues of Turkification and Islamization together with the derussification of their people.

All of these phenomena can be fully observed in Uzbekistan, which has the biggest potential for a promising future in economic, political and population terms. The degree of decolonization has proceeded so successfully that the old Communist Islam Karimov himself is considering to eliminate the economic and cultural dependency of Uzbekistan on Moscow. The Uzbek president seeks to build economic routes to the south of the country, to Karachi; to the west of the country, to the Persian Gulf; and to the east of the country, to China. ${ }^{47}$ All ambitious, and extremely independent plans of action.

\section{Notes and References}

1. Uzbek President Islam Karimov himself opposed this idea in his speech during the commemoration day marking the 75th birthday of the late Sharaf Rashidov. Please see, Islam Karimov, Xalqimizning Otashqalb Farzandi: Sharaf Rashidov Tavalludining 75 Yilliggiga Bagishlangan Tantanada Suzlangan Nutq (Tashkent: Uzbekistan, 1992), p 5.

2. Islam Karimov, Istiqlal va Ma'naviyat (Tashkent: Uzbekistan, 1994), p 25.

3. Islam Karimov, Ozbekistanning Oz Istiqlal va Taraqqiyat Yuli (Tashkent: Uzbekistan, 1992), p 6.

4. Stephen Humphreys, 'Modern Arab historians and the challenge of the Islamic past', Middle Eastern Lectures, The Moshe Dayan Centre for Middle Eastern and African Studies Publication, No 1, 1995, pp $119-131$

5. Haydarbek Bababekov, 'Mustaqillik va Igvaqarlik', Fan va Turmus, Nos 11 \& 12, 1992.

6. Cedids are the representatives of a group of Turko-Muslim intellectuals who first wanted to modernize the educational facilities of their people under the rule of the Russian autocrats in the late 19th and early 20th century. This author prefers to use 'Cedid' as opposed the Western version of 'Jadid'. However, the term has not been changed into Cedid when it has appeared in a Western publication.

7. Boribay Ahmedov, 'Amir Timurga Maktublar', Mulaqat, Nos 11 \& 12, 1992. 
UZBEKISTAN IN THE NEW WORLD ORDER

8. Ahmadali Asqarov and Boribay Ahmedov, 'Ozbek Xalqining Kelip Ciqis Tarixi', Ozbekistan Awazi, 20 January 1994.

9. According to Stephen Humphreys, op cit, 'A golden age displays to us the era in which society's key values, beliefs, and institutions were most fully and clearly realized, and thereby it identifies the moral and structural foundations of that society ... On the most general level, a golden age endows a society with its very identity and assures it of its place in the world.'

10. Donald Carlisle, 'Geopolitics of Uzbekistan', in Muslim Eurasia: Conflicting Legacies, Yaacov Ro'i (ed.), The Cummings Centre for Russian and East European Studies, The Cummings Centre Series, (London: Frank Cass, 1995), pp 90, 91.

11. An interview with Prof. Begali Kasimov by Murad Abdulla, 'Uygangan Millat Marifati', Ozbekistan Adabiyat va San'ati, 25 March 1994.

12. RFE/RL Uzbek Service archive material, 28 May 1994, cited an article in Vatan entitled 'Milliy Uyganis: Muammalar, Izlanislar, Tadqiqatlar ....

13. Edward Lazzerini, 'Ismail Bey Gasprinskii and Muslim Modernism in Russia, 1878-1914'. Unpublished $\mathrm{PhD}$ Dissertation, University of Washington, 1973. Also see, Hakan Kirimli, 'National Movements and National Identity Among the Crimean Tatars, 1905-1917', Unpublished PhD Dissertation, University of Wisconsin-Madison, 1991.

14. Adeeb Khalid, 'Printing, publishing, and reform in Central Asia', Intemational Joumal of Middle Eastern Studies, 26, 1994, p 193. Please also see, Adeeb Khalid, 'The Politics of Muslim Cultural Reform: Jadidism in Tsarist Central Asian', Unpublished PhD Dissertation, University of Wisconsin-Madison, 1993.

15. Abdujabbar Abduvakhitov, 'The Jadid movement and its impact on contemporary Central Asia' in Central Asia: Its Strategic Importance and Future Prospects, Hafeez Malik (ed.) (New York: St Martin's Press, 1994), pp 71, 72.

16. Ibrahim Yarkin, 'Bati Turkistan, Turk Dunyasi El Kitabi, (Ankara: Turk Kulturunu Arastirma Enstitusu, 1976), pp 1160-1215. The following statement was reported in p 1194; 'Guney Turkistan'da cedidciligin gelismesinde, Kirimli Gaspirali Ismail Bey'in cikardigi Tercuman gazetesinin, yeni usul ogretime ait yayinlarla Kazan ve Azerbaycan'dan gelen yayinlarin ve Turkiye'deki yenilesme ve hurriyet hareketlerinin buyuk tesiri oldu. Namik Kemal'in hurriyeti ve vatan sevgisini oven siirleri ve daha sonralari sair Mehmed Emin'in (Mehmed Emin Yurdakul), "Ben Bir Turkum" diye baslayan siirleri Turkistan aydinlari arasinda elden ele dolasarak heyecanla okundu.' (Tercuman newspapers of the Crimean Tatar Ismail Gaspirali and particularly his publication about the New Method school have played a vital role in the development of Cedidism in southern Turkistan. At the same time publications from Kazan and Azerbaijan as well as Turkey also have a share. Poems of Namik Kemal, which dealt with the love of Liberty and fatherland, as well as the poem of Mehmed Emin (Mehmed Emin Yurdakul) which is entitled 'I am a Turk' have been read by the intellectuals in Turkistan with great enthusiasm.)

17. Sabir Mirvaliyev, Ozbek Adiblari (Tashkent: Ozbekistan Respublikasi Fanlar Akademiyasi 'Fan' Nashriyaty, 1993), pp 10-38.

18. Ibid, pp 10-11, 13, 18-19.

19. Ibid, p 19.

20. Nasimcan Rahmanov, 'Turk mi yaki Ozbek mi?' Ozbekistan Avazi, 20 January 1994.

21. Qozgalis

Kisenlaring zeng basqandir, sergek bol kim uzulur;

Tamirimda qozgalisning vahsi qani kopirdi,

Eski fikir, ananeler emdi butkul uzuldu,

Ya bitermen yaki sening saltanating buzulur!

Ey sen meni qul orninda isletguci efendi!

Titre, qorq kim bagliq quling bas kotergen kuc emdi!

Ibrahim Yarkin, op cit, pp 1200-1201.

(Translation of this poem is as follows:

Beware that your chains are getting rotten,

Wild blood of revolt is boiling in my veins,

Old ideas and traditions are all ending,

Either me or your rein will perish now.

Oh you efendi who made me a slave,

Tremble and frighten that your chained slave is the rebelling force!)

22. Mirvaliyev, op cit, pp 8, 11, 18, 19.

23. Abdujabbar Abduvakhitov, 'Islamic Revivalism in Uzbekistan', in Russia's Muslim Frontiers: New 


\section{MERYEM KIRIMLI}

Directions in Cross-cultural Analysis, Dale F. Eickelman (ed.) (Bloomington: Indiana Press University, 1993), pp 81, 82.

24. Ibid.

25. Islam Karimov, Xalqimizning ..., p 6. Mustaqilliq paydavariga xalqimizning boshiga tushgan oghir kunlarda qataganlorga uchrab, gunahsiz qurbon bulgan minglab zabardast, unitilmas farzandlari tamal toshlarini kuygan. Shuning ucin xam mustabvidlik zamonida xalqimiz xotirasidan ataylab ochirilgan mutabar insonlarning nomlari birin-ketin tiklanayapti. Abdulla Kodiriy v Abdulxamid Chulpon, Abdurauf Fitrat va Usmon Nosir kabi vatanimiz, millatimiz azadligi yulida s. ketghan onlab simolarning ma'navi miraslari bugun xalkimiz bisotiga qaytmaqda.

26. Kemal Karpat, paper submitted to the SAIS (School of Advanced International Studies, Johns Hopkins University) Washington, DC, 21 March 1994.

27. Islam Karimov, op cit, Ref $25, \mathrm{p} 7$. Xalqimiz ruxaniyatining sarchashmalaridan bulmish qadimiy va navkiran Navruz ayemi, diniy qadriyatlarimizdan bulmish Ruza xayti va Qurban Xayti qaytadan xayatimizga kirib keldi. Bunday amaliy qadamlar kishilarimizda bugingi va ertangi kunga, xakimiyatga, raxbarlarga ishanc va xurmat tuygularini uygatadi.

28. Islam Karimov, Istiqlal va Ma'naviyat, p 22.

29. Islam Karimov, ibid, pp 30, 31.

30. Hidayet Diktas, 'Milletiyle Butunlesen Lider: Nazarbayev', Zaman, 6 October 1995, p 4. Hidayet Diktas is Almati correspondent of Zaman-Kazakstan.

31. A Reuter news item dated 23 September 1994, RFE/RL archive material, FF0112.

32. Muhammmed Salih, 'Ozbekistan'da Demokratiklesme Uzerine', Bitig, November 1995, No 10, pp 14-15. A publication of the Research Centre for Turkestan and Azerbaijan, Haarlem, the Netherlands.

33. Stephen K. Batalden and Sandra L. Batalden, The Newly Independent States of Eurasia: Handbook of Former Soviet Republics (Phoenix, Arizona: The Oryx Press, 1993), p 174.

34. RFE/RL Uzbek Service Archive material, 2 September 1994.

35. Islam Karimov, Xalqimizning Otashqalb Farzandi ... , p 15.

36. Islam Karimov, Istiqlal va Ma'naviyat, p 27.

37. Phillip Petersen, Security policy in post-Soviet Central Asia, European Security, Vol. 4, No. 1 (Spring 1995), pp 149-150.

38. Islam Karimov, Ozbekistanning Oz Istiqlal ... p 12.

39. Islam Karimov, Yangi uy qurmay turib, eskisini buzmang (Do not destroy your old house before you finish building the new) (Tashkent: Uzbekistan, 1993), p 7.

40. SWB, SU/2369 G/2, 31 July 1995.

41. SWB, SU/2369 G/3, 31 July 1995.

42. Petersen, op cit, $\mathrm{p}$ 152. Petersen wrote the following: '... The Uzbek intervention in Tajikistan could lead to the identification of the Karimov government with Moscow imperialism despite the fact that it is Moscow which is being manipulated by Tashkent on the political situation in Tajikistan.'

43. Petersen, op cit, p 144.

44. SWB, SU/2369 G/3, 31 July 1995.

45. Petersen, op cit, p 152.

46. Andre Grabot, 'Uzbekistan President in China', AFP, 23 October 1994, RFE/RL Archive material FF0054, 23 October 1994.

47. Islam Karimov, Istiqlal va Ma'naviyat, p 28. 